\title{
Albania's European Perspective and the Albanian Politics
}

\author{
Dr. Adelina Nexhipi \\ Erjon Nexhipi \\ Phd. candidate
}

\begin{abstract}
Albania's EU integration has been an important part of politics of all Albanian governments after 1990s. This process has been considered not only as a means for being a part of the United Europe, but a factor for achieving the stability in the country, economic development, strengthening democracy. Diplomatic relation between Albania and the EU were established since 1991, but Albania's European perspective was ensured only in 1999, by signing the Stabilization and Association Agreement. Since 1999 onwards the Albanian governments have been working for fulfilling the membership criteria to European Union, though the process has been a long and problematic one. Nowadays (2019) Albania expects the EU to open the negotiations for the EU membership process. Through this descriptive-analytical study, we will shed light into the most important moments of the Albanian process toward the European integration; policies followed from both parties, attitudes of the Albanian politics, encountered difficulties, problems and achieved successes. The study relies on the many documents from EU and Albanian institutions such as studies, analyses, interviews with political personalities, Albanian and European researchers and analysts. The study aims to analyze the "long and difficult" path of Albania towards EU, focusing on what has been achieved and the future challenges.
\end{abstract}

Keywords: Albania, European Union, European perspective, European integration.

\section{Introduction}

Albania's diplomatic relations with the EU were established in 1991. On May 11th 1992 the Trade and Cooperation Agreement was signed including the common declaration on political dialogue, which came into force on December $1^{\text {st }}$, 1992. The Agreement of 1992 was not just an act regulating the economic and trade relations among the parties, but it was an important document which paved the way for closer relations, based on the principle of democracy consolidation and achievement of Albania's goal for being an EU member; although the goal of the agreement was not Albania's EU membership. The agreement offered less than other agreements that were signed later with the countries of Eastern and Central Europe. However, referring the political changes in country, the agreement recognized the Albanian' willpower for stability and democracy consolidation based on European principles.

According to the agreement, Albania was involved on the Generalized Scheme of Preferences - a regime that EU offered to a number of countries that had contractual relations with. EU became the main donor for Albania. It benefited from the assistance offered from EU to the Southeastern Europe countries through PHARE program. According to Vurmos, "until 1994, the Albanian economy was not able to benefit from the preferential treatment offered by the Union. The Albanian exports remained in low levels compared to imports. The systematically high trade deficit made the Albanian economy a market oriented towards imports"1

Albania proved better conditions for a fast development, which in 1995 made the Albanian authorities take the first steps towards starting the negotiations about the Association Agreement with EU. After coming out of the emergency situation of systems transition, through an official request, Albania asked to open the negotiations for an association agreement to EU. Though, during this period the results could not be positive yet, since the country's progress was not on the right levels. The estimation was made after this request. In this case, the European Commission which was in charge of the estimation, pointed out the priorities that Albanian should have to follow in regard to its EU integration process. Therefore, in estimating

${ }^{1} \mathrm{Gj}$. Vurmo, Relations of Albania with the EU, Institute for Democracy and Mediation, Tiranë: 2008, 33 - 34 
the opportunities for free trade of goods and services, Albania was still too far from parameters and requests of the Union and as such the request was considered "a premature step".

In the framework of the dialogue between Albania and EU, 4 ministry level meetings and 5 inter-parliamentary meetings were held during 1994 - 1998. There was discussed the legislation approach, custom cooperation, economic and financial issues, agriculture and infrastructure. Until then, EU was not concretely involved regarding to the membership perspective for the West Balkans countries.

As far as the regional access was concerned, EU gave preferential asymmetric tariffs to Albania and other West Balkans countries aiming the support of a closer economic cooperation with the member countries in 1998. The agreement provided preferential tariffs on imports from Albania for a three-year period. In order to enter West Europe goods into EU, another agreement was arranged form Albania. This agreement removed the duties for some industrial goods entering the EU from Albania. Regardless the priorities of this agreement, still Albania was non-competitive in the European market, because of the low level of economic development and higher safety EU standards, especially for the alimentary products.

In May 1999, EU adopted a new initiative for 5 Balkan countries: Albania, Former Yugoslav Republic of Macedonia, Croatia, Bosnia and Herzegovina and the Federal Yugoslav Republic, called the Stabilization and Association Process. The agreement was signed in a time when hostilities and victimizing created a mosaic of polarized countries in the Balkans. In the majority of countries, the fight, lack of consensus on reforms, poor experience in democratic governance and poor institutions interfered with the political and economic progress. Delays and barriers created in implementing the programs and reforms were characterized by poor economic results, decline of living standards, unemployment, and poverty in the Balkan countries. The agreement represented one of the most important concrete initiatives in the Southeastern Europe and was considered an important instrument in facing the crisis and starting a sustainable development process in the region. ${ }^{1}$

The Pact of Stability was not a direct instance of the European Union; it was under the auspices of OSCE. Partners of the Pact of Stability were more than 40 countries and organizations. * There was determined in the foundation document the EU's "leading role", not only in the initial phase, but concrete structuring of the Pact as well (Article 18). In this framework, all "respective programs" on fostering democratic and economic institutions (Article 19) and those activities which would give the Southeastern Europe countries a full EU integration perspective, were welcome.

The Stabilization and Association process was not a simple bilateral process with each country. Moreover, it was a process which should develop the regional cooperation between the countries involved in it. To anticipate any undesirable development in the region, the EU countries paid special attention to the need of these countries to cooperate among them, aiming the democratization of the region and the establishment of a common market, mainly among these countries. By supporting the domestic reforms and the close cooperation with their regional neighbors, the EU initiative aimed to help these countries in improving their perspective for an EU membership. The Pact gave high expectations in Southeastern Europe countries and the EU too. It established a cooperation climate in the region by concentrating the resources, human potentials of all West Balkans countries on the integration process. Serb scholar, Ana Marjanović Rudan argues: "For the first time in its contemporary history, West Balkans, as a multi-ethnic region, found itself in a situation where countries were not challenging each-other, but were on the same side focusing on the same goal: the European integration."2

The main objective of the Pact was to ensure peace, wellbeing and stability in the region through regional cooperation. In order to achieve it, initiatives undertaken from the Southeastern Europe countries on peace, democracy and human rights, economic wellbeing and their integration in Euroatlantic structures should be supported. Main tasks of the Stability Pact included: establishment of a new political order and democratic institutions; (ii) economic reconstruction and wellbeing; (iii) establishment of a safe environment relying on the rule of law.

Since the beginning of this new initiative, Albania became part of it. The process aimed to establish closer relations between the EU and the above mentioned countries through Stabilization and Association Agreement (SAA) which could be rather

\footnotetext{
1 The World Bank, Europe and Central Asia Region, "Stabilization and Association Process in the Balkans," Policy Research Working Paper 3108, August 2003, 9

*EU and its Member States, USA, Canada, Japan, Russia, NATO, OSCE, Council of Europe, IMF, World Bank and EBRD

${ }^{2}$ A. Marjanović Rudan, "Advocacy Strategy for the EU Integration of the Western Balkans - Guidelines," in Advocacy Strategy for the EU Integration of the Western Balkans, European Movement in Serbia, Belgrade: 2016, 4
} 
considered as matured reflections of European agreements. In order to clarify the somewhat complicated term of stabilization and association, it is appropriate to refer the clarification of the EU commissioner on enlargement, Mr.Rehn: "SAA is a combination of further development of markets, free trade, taxes and financial assistance for the West Balkans countries, and also, foster the political dialogue and establishment of contacts among the people in EU and West Balkans. In other words, SAA is the cornerstone towards the European Union."1. In November 1999, the European Commission presented a report on the feasibility study for starting the negotiations with Albania for signing the SAA, resulting that Albania had not met the conditions for such an agreement.

The perspective of western region countries for EU integration was consolidated after the European Commission of Feria, organized on June 2000. It decided that all countries involved in the SAA were potential EU candidates. It followed the meeting in November 2000 in Zagreb where countries involved in the SAA process were invited. It was not a happy event for Albania since its second effort for improving the contractual relations with EU failed. The country was not prepared sufficiently. However, EU decided to intensify the cooperation with Albania by creating the High Level Leading Group: Albania - EU. Its objective was to estimate Albania's capacities in undertaking the tasks for a SAA with the EU.

High level leading group Albania - EU held three meetings in Tirana, resulting in the European Commission to write an evaluation report where the progress made until now and sectors that still needed improvement were identified. In the beginning of 2001, the Commission estimated that although many tasks needed to be completed, the perspective of starting the negotiations was the best way for preserving the temper of political changes and economic reforms in country. ${ }^{2}$ For this reason, the Commission concluded that it was the moment for proceeding with a SAA with Albania. "It was a decision mainly political, according to Vurmos - because the progress made in 1999 - 2001, was not sufficient for justifying this step, as the European Commission concluded itself." 3

In June 2001, The EU Council of Ministers adopted the Commission's report and asked it to present a project-mandate for starting the negotiations with Albania before the end of 2001. In accordance with the Council's request, in December 2001, the European Commission presented the project-mandate of negotiation of a SAA with Albania. Also, it was decided to create a Consulting Group EU - Albania.

In response to the European Commission request for providing a necessary partner structure for developing bilateral discussions between the EC and the Albanian government, there was established in October 2001 the structure of the Ministry of Integration, Department of European Integration, structure of the Council of Ministers, whose task was to treat issues related to the integration progress, preparation of the country for starting the negotiations, negotiation processes, signing and monitoring the implementation of SAA.

The project-mandate of negotiations, prepared and presented by the EC was discussed on technical level from the EU member countries during January - July 2002. The Council of General Issues of EU, during its meeting on October $21^{\text {st }}$, 2002, decided to start the negotiations with Albania. They started officially from the President of the European Commission, Mr. Romano Prodi on January, 31st 2003 . The first negotiation meeting was held on February $13^{\text {th }}, 2003$. The Albanian delegation was leaded by the Minister of European Integration and was made up of experts from different areas, (depending on issued to be discussed), whereas the European party the negotiations were conducted by the EC representative for Albania. A total of 18 rounds of negotiations were held: 7 political and 11 technical. ${ }^{4}$ During the discussions was decided that the Albanian government apply the necessary reforms, to ensure that it was able to perform the SAA tasks as needed. Negotiations would end after the Commission and Council's evaluation accepted the conclusion of the process. The Commission would use monitoring instruments to evaluate the progress made from Albania in implementing different reforms. Time for closing the negotiations would be determined from the pace and quality of reform implementation.

A very important moment for getting the West Balkans closer to EU was the Thessaloniki Summit in 2003. Writing and approving the document from the EU "Thessaloniki agenda for the West Balkans - Towards the European Integration",

\footnotetext{
11nterview with Olli Rehn, EU Commissioner for Enlargment, Brussels on 13.2.2006 [online] available in: http://www.seetv-exchanges.com/, retrieved on 15. 12. 2012

2 European Commission, How does a country join the $E u$, [online] available in:

http://ec.evropa.eu/enlargement/enlargement_process/accession_process/how_does_a_country_join_the_eu/sap/zagreb_summit_en.ht $\mathrm{m}$, retrieved on12. 09. 2012

${ }^{3} \mathrm{Gj}$. Vurmo, Relations of Albania with the EU, Institute for Democracy and Mediation, Tiranë:2008, 23

${ }^{4}$ ITAP, Çështje të eksperiences lidhur me PSA dhe MSA, pjesa I, 13
} 
was an important step in developing the relations further between the EU and SAA countries, especially pointing out the perspectives of EU membership of these countries. There was no doubt during the summit that the progress of towards the European integration depended on the individual performance of each of the West Balkan countries in relation to the economic and democratic reforms, respecting the human rights, good governance and respect for the rule of law. In developing the regional cooperation, the summit encouraged free trade on regional level, creation of regional markets of power and gas, development of energy, transport, telecommunication and infrastructure, environmental protection, research and development technology, border cooperation, etc. The part that described the EU evaluations for each West Balkans countries, for Albania it stated that "political stability and the progress of reforms allowed for starting the negotiations with Albania for a SAA. Consolidation of the good political climate and a sustainable policy for reforms remains a pre-condition for further progress towards the EU. The focus should be on effective application of reforms. " 1 In this context, the Council also pointed out the importance of undertaking the necessary measures for Albania to build those missing capacities for achieving the future agreement.

In complying with the commitments of Thessaloniki Agenda, on March 30th 2004 , the European Commission presented the European Partnership for Albania, based on the Accession Partnerships model for the candidate countries joining the Union on May 1st, 2004. The Partnership Document determined the short and midterm priorities of the country towards the European integration. It served as a framework for objectives and criteria whose would serve as basis for measuring the Albania's progress towards the Stabilization and Association process. It was also a framework for addressing the community's financial assistance through CARDS program. On the other hand, the Partnership Documents as based on annual reports, would help the governments of the SAA member countries to concentrate their reform efforts and possible resources where needed the most.

The European Partnership for Albania was approved by the EU Council of Ministers in July 2004. Albania should undertake important and urgent reforms, especially in the fight against organized crime, trafficking and corruption; strengthen the judicial system and public administration; ensure the right functioning of democracy (including elections) and preserve the political stability necessary for quick implementation of reforms; improvements on human and minority rights; further formalization and reforms in economy; increase of fiscal sustainability through more efficient custom and tax administration and a stronger legal framework. ${ }^{2}$

Negotiations on SAA between Albania and the EU extended three times more than negotiations between the EU with Croatia and Macedonia because of the slow reforming process in Albania, especially the fight against corruption and organized crime. Three years of negotiations were needed for Albania until in February 2006 in Tirana the Stabilization and Association Agreement was stipulated and in June 16 $6^{\text {th }}, 2006$ in Luxembourg, at the Council of General and Foreign Issues, the Stabilization and Association Agreement and Temporary Agreement on Trade and Commercial Cooperation were signed.

On one hand, the objective of the Stabilization and Association Agreement was to bring Albania closer to EU by creating mechanisms allowing cooperation on common interests of parties, and to not affect on the other hand the foundations of European structure by having its core element "acquiscommunautaire". Since the agreement aimed to establish the political and economic stability of the candidate state, there were asymmetric tasks in its favor. The asymmetrical application of tasks provided at the SAA had to do on one hand with the free movement of goods and key fields related to the application of this freedom on the other. Besides asymmetrical custom liberalization, the Community made concessions on key fields of applying the common market, mainly on competition, liberalization of land market, state subsidies and public procurement. Another aspect of the asymmetry of applying the SAA was the financial assistance granted by the European Commission for achieving its objectives.

In order to be part of the Agreement, Albania needed to comply with the criteria determined by the European Council of Copenhagen in June 1993. These criteria are political and economic. The candidate state for integration should ensure democracy, rule of law, application of the human and minority rights, provide a market economy able to face the competition pressure of the European common market and be able to respond the obligations resulting from "acquis communautaire" EU legislation.

\footnotetext{
1 "Thessaloniki Agenda for Western Balkans - Towards European Integration", [online] available in: http://eur-lex.evropa.eu/LexUriServ/LexUriServ.do?uri=COM:2003:0285:FIN:EN:PDF, retrieved on12. 08. 2012

2 European Commission, Staff Working Paper, Albania, Stabilisation and Association Report 2004, Brussels, April 2004, Com (2004) 203 final
} 
$\mathrm{EU}$, on the other hand, should support the Agreement signing country in its own democratic and integrating processes. According to SAA, (Article 1), the EU would: (i) support Albania's efforts in strengthening the democracy and the rule of law; (ii) contribute on political, economic and institutional stability in Albania and regional stability; (iii) ensure a suitable structure for the political dialogue allowing the development of close political relations between parties; (iv) support Albania's efforts on developing the economic and international cooperation, also through approaching both its legislation and Community's; (v) support Albania's efforts to complete the transition in a functional market economy, provide economic relations and develop gradually a free trade area between the Community and Albania; (vi) stimulate regional cooperation in all areas affected by the Agreement. ${ }^{1}$ It should be made clear that the objective of the Agreement was radical integration, and not development and reduction of poverty in itself. While the development and reduction of poverty are considered important, the process in itself was supposed to make them follow the integration process. ${ }^{2}$

The general framework of SAA was made up of four pillars: (i) political dialogue and the regional cooperation; (ii) Trade dispositions related to progressive exchange liberalization until establishing a free trade area among parties; (iii) community freedom; (iv) cooperation on priority areas, especially in justice and internal issues. Political dialogue would be handled in the Stabilization and Association Council. It aimed to bring Albania closer to EU, based on parties' attitudes on international issues, safety and stability in Europe, regional cooperation, development of good neighborhood relations. Trade dispositions aimed to gradually establish a free trade area during a 10-year period from the Agreement coming into power, invalidate custom duties on imports towards Albania for the goods originated from the Community and vice versa, administrative cooperation to fight against irregularities and custom fraud, removing barriers on transport for goods and services. Community freedom implied free movement of employees working legally in the territory of a member country, the right of economic and professional activity for each citizen, in every member country, free movement of capital. Legislation approach made Albania ensure that its existing laws and future legislation comply gradually withacquis communautaire. Cooperation on priority areas, especially on justice and internal issues encouraged parties to pay special attention to strengthening the rule of law and institutions on all levels, administration in general and laws on managing the justice system. Cooperation aimed especially the independence of the judicial system and improvement of its efficiency, improvement of police functioning and other law institutions by ensuring training and fighting corruption and organized crime. Economic cooperation aimed the formulation and application of economic policies in the market economy, approach of policies with stabilizing EU and monetary policies, strengthening of the rule of law in business, informal information exchange related to principles and functions of Economic and Monetary European Union, cooperation in developing an efficient system for Internal Public Financial Audit and external audit systems in Albania, in accordance with widely accepted standards and methodologies, cooperation in the aspect of encouraging and protecting the investments, cooperation in tourism and agriculture, cooperation in tax and fiscal reforms. Social cooperation consolidated the cooperation on cultural, education, environment, scientific and technological aspects and public administration as well. ${ }^{3}$ SAA put forward a reciprocal commitments framework for a wide range of political, trade and economic issues. The agreement should be applied progressively and fully completed during a transitory period of a maximum of 10 years.

Since signing the SAA until its coming into force, another agreement was signed which aimed to adjust the relations between Albania and EU: "Temporary Agreement between the Republic of Albania and the European Community for Trade and Trade Cooperation" (Interim Agreement, 8154/06). It established solid basis of reciprocity related to duties and rights in trade. Thus, the agreement specified that "The Community and Albania should gradually establish a free trade area for a maximal period of 10 years, starting from the date of its coming into force" (Article 3 ). ${ }^{4}$ A series of benefits were listed on the Temporary Agreement, such as reduction to zero the custom tariffs for industrial products and several Albanian agricultural processed products, whereas for other products would be gradual reduction (Annex I). Also, Albania benefited from the autonomous trade measures granted by EU. Furthermore, in order to eliminate non-tariff barriers and prepare Albania to participate in the internal European market, it was necessary to achieve a progressive harmonization of laws and regulations with those of "Acquis communautaire" for the internal European market.

\footnotetext{
1 Stabilization and Association Agreement between EU and Albania, Official Journal of the European Union, L 107/166, 28.4.2009, 8

2 Y. Zahariadis, The Effects of the Albania-EU Stabilization and Association Agreement: Economic Impact and Social Implications, ESAU Working Paper 17, ODI, London: 2017, 1

${ }^{3}$ Stabilization and Association Agreement between EU and Albania, Official Journal of the European Union, L 107/166 28.4.2009

${ }^{4}$ Council of the European Union, Interim Agreement on Trade and Trade-Related Matters between the European Community and the Republic Of Albania, Brussels: 22 May 2006, 8154/06 COWEB 73
} 
On July 2007, new Central Europe Free Trade Agreement (CEFTA) came into force and Albania along with Croatia, Macedonia, Serbia, Bosnia and Herzegovina, Montenegro and Moldova signed and ratified the agreement. It was important for establishing a more advanced regional area for free trade, to integrate the customs legislation of accepted countries and also for the preparatory stage for a future EU membership. EC supported CEFTA, both through technical assistance and three-year CEFTA financing.

After signing the SAA, a series of plans and strategies detailed the approaching program of the Albanian legislation with acquis. Serious efforts were made in 2007 by adopting the National Plan for Legislation Approach especially the adoption of National Plan for Applying the SAA 2007-2012 which planned the country to take fast steps in applying the conditions provided at the SAA; "benefiting the status of candidate country for EU membership within a two-year period; full completion of standards for EU membership."1 The strategy gave in further details the objectives of approaching the legislation by establishing concrete expectations in timely terms. Such strategy determined the expectations for approaching the legislation in two 5 -year stages.

SAA was ratified from all EU member countries and on April 1st 2009 it entered into force. Right after, (on April 28 $8^{\text {th }}, 2009$ ), the Albania government submitted its application for EU membership. In response to its request for membership, EU on November $16^{\text {th }}$, asked the EC to write and submit Albania the questionnaire for preparing its opinion on obtaining the status of candidate country. It was submitted on December, $16^{\text {th }}, 2009$. After an intensive work from the Albanian party, the responses to the questionnaire were officially submitted in Brussels on April 14 $4^{\text {th }}, 2010$.

In order to realize the political promise made in Thessaloniki Summit where EU among others was committed to liberalize the visas with the West Balkans, in June 2008, the vice President of EC, Franko Fratini, submitted a Guide for liberalization of visas for Albania and Bosnia and Herzegovina. The Guide written in four sections contained duties of technical nature: (i) document safety; (ii) migration, border management and reacceptance; (iii) public order and safety; (iv) foreign relations and fundamental rights.

During the first estimations, (March - May 2009), EC considered that Albania had made obvious progress, but also it identified a few sectors where further repairs were needed; one of the key tasks was production and distribution of biometric passports. The European Commission evaluated in April 2010 that Albania had made considerable progress in all areas covered by the Guide and considering the estimation, the Commission on May $27^{\text {th }}, 2010$, submitted the proposal to the European Parliament and the EU Council for removing the visa regime for Albania, by presenting three sub-issues which should be met by Albania: (i) writing and approving a strategy for re-integrating the Albanian returned or re-accepted citizens; (ii) monitoring the work of Albanian authorities in applying the law for confiscating criminal assets (antimafia law); (III) further strengthen the capacities of law enforcement institutions against organized crime and corruption, as provided in the strategies and respective action plans. ${ }^{2}$ On July $8^{\text {th }}, 2010$, the European Parliament passed the Resolution "On Albania's European Integration" and in November the Parliament passed the decision for removing the visas for Albania, which came into force on December $15^{\text {th }}$.

During 2010, Albania was caught in a long parliamentary and political crisis, a situation which came as result of parliamentary elections of June $28^{\text {th }}, 2009$. The Socialist Party considered the elections as manipulated and votes stolen, it did not recognize the result and boycotted the Parliament on conditions that the poll boxes are opened for an election transparency. The crisis reached its highest levels on April $30^{\text {th }}$, when 22 parliamentarians from SP and 180 SP fans into on hunger strike for 19 days. They requested to open the poll boxes, vote re-counting and election transparency. During 2010, the political situation was difficult. During parliamentary sessions, time was wasted on mutual accusations, insults and physical crashes without discussing and passing laws. Parliamentary malfunctioning resulted in delays in passing laws as recommended from the European Commission, blocking the normal work of the state. An example of that was approval of amendments of the Law on National Judicial Conference (requiring $3 / 5$ of the votes at the Parliament). These delays blocked the replacement of judges at the Higher Council. At the progress-report in 2010 for Albania, the European

\footnotetext{
${ }^{1}$ Këshilli i Ministrave, Strategjia kombëtare për zhvillim dhe integrim 2007 - 2013, Mars 2008, final, 15

2 D. Avdyli, G. Bektashi, "Shqipëria në procesin e liberalizimit e regjimit të vizave të BE-Hapat dhe reformat e ndërrmara," in Third International Conference on Business, Law, Administration and Social Sciences, TBU, Tiranë 2015, 516
} 
Commission pointed out that "the political cramp is damaging the democracy in Albania and is preventing important reforms which are necessary for the country's progress towards the EU integration and rule of law function."

Parliamentary cramp, harsh political debate, lack of consensus among the parties in fulfilling the tasks defined by the European Commission made that Albania received a negative response to its request for benefiting the status of the candidate country. In its opinion on the Albania's request, the Commission listed Albania's achievements on economic level, legal structure, approach of legislation with the acquis communautaire, good neighborhood policies, meeting the SAA conditions, but for the most port the document listed the actual problems of the country: lack of efficiency and stability of democratic institutions, non-constructive and conflicting political dialogue, problems in law application, politicized public administration, very politicized election processes and non-accomplishment of OSCE recommendations, lack of independence, transparency and accountability on judicial system, lack of concrete plans against corruption and organized crime, media independence being at risk from the political influence and business interests, wide criminal activity, neglecting the human rights by courts and administration, discrimination of marginalized groups, high unemployment, high public debt, informal employment, poor infrastructure. Regarding the meeting of Copenhagen criteria on EU membership, the Commission argued that Albania has made a lot of progress in meeting the political criteria, but still a lot needed to be done. As far as meeting the economic criteria was concerned, a certain level on macroeconomic stability was achieved, but in order to build a functional market economy, Albania needed to strengthen its governance, law system, improve the labor market, ensure and acknowledge the property rights, strengthen physical infrastructure and human resources and provide a competitive market in the European market. In approaching the legislation with EU acquis progressive work has been done, but special attention should be paid to laws on free movement of goods, intellectual property, media, food safety, agriculture and rural, social development, employment, etc.

After this analysis, the Commission decided that "negotiations on EU membership should open with Albania just when the country reaches the right level of meeting the membership criteria, especially the political criteria of Copenhagen which require the institutional stability and ensure democracy and rule of law."2 The European Commission submitted to the Albanian government 12 recommendations (key priorities) to be met, in order to obtain the status of candidate country:

1. Ensuring a good functioning for the Parliament based on a constructive and sustainable political dialogue among all political parties.

2. Approving pending laws which require a Parliament majority.

3. Appointing the Ombudsman and ensuring a regular hearing and voting process in Parliament for appointing at the Constitutional and Supreme Courts.

4. Modification of the legal framework for elections, in accordance to OSCE-ODIHR recommendations.

5. Holding elections based on European and international standards.

6. Essential full steps in public administration reform.

7. Fostering rule of law through approving and applying a reforming strategy for the justice system, ensuring independence, efficiency and accountability of justice institutions.

8. Effective application of the strategy and the Government's action plan against corruption on all levels.

9. Intensification of the fight against organized crime.

10. Preparation, approval and application of a national strategy and action plan on the property rights.

11. Undertaking of concrete steps in protecting the human rights, especially women, children and Roma people and applying anti-discrimination policies effectively.

\footnotetext{
1 European Commission, Staff Working Paper, Albania 2010 Progress Report, Bruksel: 9 nëntor 2010, COM (2010) 680, 12

${ }^{2}$ European Commission, Commission Opinion on Albania's application for membership of the European Union, Brussels, 9.11. 2010, $\operatorname{COM}(2010) 680,11$
} 
12. Undertaking additional measures for improving the treatment of detained persons in police stations, custody and penitentiary institutions. ${ }^{1}$

The events happening in Albania in 2011 *displaced the institutions' attention from the necessary reforms for EU integration. The progress report from the European Commission for Albania in 2011 was mainly focused on the Commission's analysis for the work done from Albania in 2011 in meeting the 12 set priorities. The Commission's estimation was that Albania had made little or no progress (in different areas) in completing the 12 key priorities. The entire analysis included such specifications as "no progress made", "limited progress" or "efforts for improvement". According to the progress report, the cause of all these failures was the political cramp prevailing the country. Regarding the 12 key priorities, the European Commission estimated that in general the right functioning of the Parliament based on a constructive and sustainable political dialogue among all parties was not achieved yet; important laws requiring $3 / 5$ of the votes and a consensus between the position and opposition were pending. No progress was made related to the efficiency of the legal system, the changes in the election legislative framework based on OSCE/ODIHR recommendations; election reform was blocked by the political cramp and lack of dialogue among the main parties. The election process only met the standards and best international practices partially. Very little progress was made in reforms in public administration and in judicial system, fight against corruption within the judicial system. Also, little progress was made for the anti-corruption policies, in creating a solid sequence of proactive investigations, prosecuting and punishing the corruption cases on all levels. Little progress was made for the correctional facilities, although there were problems in treating the socially vulnerable/disabled people. Little evident progress was made in preparing a comprehensive strategy on the property reform. ${ }^{2}$ As a consequence, the European Commission provided a negative opinion concerning the progress made from Albania and its request on obtaining the status of the candidate country.

2012 was a working year for Albania in meeting 12 priorities set by the EC. In this regard, the Action Plan for completing the Opinion's recommendations was approved on March; the meeting of the Stabilization and Association Council was held in May; changes made on the National Plan for SAA application were approved by decision of the Council of Ministers ion July 2012. In the end of 2012, the European Commission evaluated the progress made by Albania related to meeting the 12 key priorities. According to the Strategy for EC Enlargement document 2012 - 2013, "Albania has made progress in meeting the political criteria for EU membership, by undertaking a series of reforms based on 12 key priorities."

According to EC, Albania met 4 of the set priorities: (i) well-functioning of the Parliament, (ii) Parliament approval of laws requiring the majority, (iii) approval of changes on the election legislation, (iv) appointing the Ombudsman and parliamentary hearing sessions for appointing in important institutions. Albanian was on a good road towards meeting with two criteria: (i) civil administration reform and (ii) improvements in treating the detained persons. Moderated progress (insufficient) was made in: (i) reform in the justice system, (ii) fight against corruption and (iii) organized crime, (iv) property rights, (v) antidiscriminating policies, (vi) women rights. Albania needed to intensify the progress and take concrete steps in applying the judiciary reforms in order to achieve independence, efficiency and accountability in the justice system; public administration reform and parliamentary regulation should be complete and more attention should be given to the application of the human rights, especially in improving the living standards of the Roma people, application of law and continue with the political dialogue. ${ }^{4}$

Relying on the progress already made, the Commission recommended that the Council provided Albania with the status of the candidate country, because it had made necessary progress. The Commission would report to the Council as soon as

\footnotetext{
1 European Commission, Commission Opinion on Albania's application for membership of the European Union, Brussels, 9.11. 2010, $\operatorname{COM}(2010) 680,11-12$

*During 2011, Albanian political life was shaken by: the publication of a video involving the deputy prime minister in corrupt affairs; the anti-government protests organized by the opposition on January 21, which left 4 protesters dead and several others injured; from the deep political debate over the announcement of the results for the Municipality of Tirana during the local elections of May 8, 2011.

Thereafter, the SP accused of manipulating the election results and again boycotted the assembly, which lasted until September 5 .

2 European Commission, Staff Working Paper, Albania 2011 Progress Report, Bruksel, 12.10.2011, COM (2011) 666 final, 8 - 25

3 European Commission, Enlargement Strategy and Main Challenges 2012-2013, Brussels, 10.10.2012, COM(2012) 600 final, 14 ${ }^{4}$ lbid, 15
} 
it identified results in applying the reforms in the public administration, courts and parliamentary regulation. Holding parliamentary elections in 2013 was a precondition recommending the start of negotiations. ${ }^{1}$

Parliamentary elections in June 23,2013 as a precondition for obtaining the status of the candidate country were considered a successfully passed test for Albania. The progress report of the European Commission in 2013 argued that "In general, elections marked a tangible progress compared to past practices by meeting the key priority regarding the elections"2. The European Commission, having analyzed the Albania's progress during 2013, recommended to the European Council that Albania be given the status of the candidate country, since it had made the necessary progress. Therefore: addressing to the fight against corruption and organized crime, Albania has undertaken elementary steps towards improving the efficiency of investigations, prosecution and fostering cooperating among law application institutions..... All the European Commission's last recommendations related to financing the political parties and legal dispositions on corruption are addressed satisfactorily. ${ }^{3}$

Following the Opinion of 2010, the Commission set 5 priorities on starting the negotiations on EU membership process:

1. Application of public administration reform in 0 order to increase the professionalism and depolitization of the public administration;

2. Further actions in fostering independence, efficiency and accountability of judicial institutions;

3. Further efforts against corruption, aiming to establish a permanent registry of proactive investigations, prosecutions and punishments;

4. Further efforts in the fight against organized crime, including the establishment of a permanent registry of proactive investigations, prosecutions and punishments;

5. Effective measures in protecting the human rights, including Roma people, anti-discriminating measures and property rights to be applied. ${ }^{4}$

The first meeting of the High Level Dialogue EU - Albania on the key priorities took place in November $12^{\text {th }}, 2013$. The same month, the Parliament passed consensually a resolution on the European integration of Albania, by ratifying a series of important measures for EU integration, mainly rule of law. During 2014, the Albanian government was committed actively along with EC to structure its efforts in addressing the main priorities; it approved the National Plan 2014-20 on the European Integration, established a network of integration units at the ministries for identifying the priority objectives of its policies and monitor the progress for their completion. Six key priorities were identified and 56 priorities of ministries and a matrix of expected results was drafted. 6 key priorities set on the National Plan were: (i) European integration; (ii) good governance, democracy and rule of law; (iii) growth through economic and fiscal stability - fight against informality; (iv) economic growth through increase of competitiveness; (v) investment on individual and social cohesion; (vi) growth through sustainable use of resources (integrated water management, power, land) and territory development. ${ }^{5}$ Application of the plan would be monitored through performance indicators regularly.

According to EC, during 2014, willingness for acting firmly was shown in the fight against corruption, reforms showed a comprehensive approach including a wide range of institutions. Important legislative reforms were undertaken in the fight against organized crime and investigations provided positive results in the fight against drug trafficking and organized crime. Albania showed its dedication on judicial reform, especially by working with the Venice Commission to improve independence, accountability and professionalism of the judicial system. ${ }^{6}$ Based on the developments in Albania, "the Commission confirms its recommendations that the European Commission should give the candidate status to Albania"7

\footnotetext{
${ }^{1}$ European Commission, Enlargement Strategy and Main Challenges 2012-2013, Brussels, 10.10.2012, COM(2012) 600 final, 27

${ }^{2}$ European Commission, Staff Working Paper, Albania 2013 Progress Report, Bruksel: 16.10.2013, COM (2013) 700 final, 6

${ }^{3}$ European Commission, Enlargement Strategy and Main Challenges 2013 - 2014, Brussels: 16.10.2013, COM (2013) 700 final,18 - 19

${ }^{4}$ Ibid, 19

${ }^{5}$ Këshilli i Ministrave, Plani Kombëtar për Zhvillim dhe Integrim 2014 - 2020, Draft, qershor 2013

${ }^{6}$ European Commission, Albania's Progress in the Fight Against Corruption and Organised Crime and in the Judicial Reform, Brussels:

4.6.2014, $\operatorname{COM}(2014) 331$ final, 11

${ }^{7} \mathrm{lbid}$
} 
On July 24th 2014 , the Council of General Issues of the European Union decided that Albania be given the status of EU candidate, for "appreciation for applied reforms, and encouragement as well for increasing the flow of reforms"

In its strategy for enlargement for 2014 - 2015, the European Commission, while treating the progress of reforms in West Balkans, pointed out especially three main pillars where reforms should continue: rule of law, economic governance and public administration reforms. ${ }^{2}$ The European Commission in estimating that "corruption still remains a serious issue", set these tasks to West Balkans countries:

Ensuring a strong framework for preventing corruption, with further necessary efforts related to financing the political parties and election campaigns, management of conflicts of interest, transparency in using public funds, and confiscation of property.

Public administration reform and management of public funds.

Improvements in collecting and access of data that are necessary for improving the transparency and monitoring the application of anti-corruption policies in services such as education and health.

Means for preventing corruption effectively were less used. There was a need for a more active, coordinated and efficient application of law.

Fight against organized crime and corruption was essential against crime and criminal infiltrations in judicial, political and economic systems.

Institutions of law application, prosecutor's services and judiciary needed to become more elastic against corruption, perform more controls in identifying legal businesses which make up a place for criminal activities.

Capacity for performing financial complex inspections and treating money laundry needed further improvements and new threats such as cyber crime needed to be addressed. ${ }^{3}$

Albania and EU continued with the high level dialogue on meeting 5 priorities; Albania went on with integrating its own legislation with the EU's demands in a number of areas, increasing thus its capacities in taking over membership obligations. During 2015 onwards, the Albanian government worked on meeting the 5 priorities for starting the negotiations with the EU; a new Code of Administrative Procedures was approved; new territorial reform was ratified and the National Agency for Territorial Reform Application was established. The process of legalizing illegal constructions was intensified throughout the entire country, the new anti-corruption strategy (2015-2020) and Action Plan 2015 - 2017 were written; laws on fighting the organized crime and cannabis cultivation were enforced. Special attention was given to the reforms in the judiciary system: ad hoc parliamentary commission for preparing the justice reform was established: it aimed to fight corruption in justice and build an efficient system which is professional and politically independent; constitutional amendments in order to apply the reform and about 40 laws on its application were approved. They included procedures for re-evaluating the judges and prosecutors and all the necessary structures for applying the reform.

In November 2016, the European Commission estimated that Albania was "moderately prepared" in opening the membership negotiations and "recommended opening accession negotiations with Albania subject to credible and tangible progress in the implementation of the justice reform, in particular the re-evaluation of judges and prosecutors (vetting)"4. One year later (2017), although EC appreciated the reforms undertaken in Albania, it insisted on applying the reforms and their tangible outcomes. In the meantime, the 2018 evaluation was more positive and hopeful, arguing that Albania had already made "some level of preparation" in meeting 5 priorities and "the Commission recommended that the Council decides that accession negotiations be opened with Albania, at the same time encouraging Albania to maintain and deepen the current reform momentum, in particular in the key field of the rule of law"s.

\footnotetext{
${ }^{1}$ European Commission, Staff Working Paper, Albania 2014 Progress Report, Brussels: 8. 10. 2014, COM (2014) 700 final, 1

2 European Commission, Enlargement Strategy and Main Challenges 2014-15, Brussels: 8.10.2014, COM(2014) 700 final, 1

${ }^{3}$ European Commission, Enlargement Strategy and Main Challenges 2014-15, Brussels: 8.10.2014, COM(2014) 700 final, 11 - 12

${ }_{4}^{4}$ European Commission, Commission Staff Working Document Albania 2016 Report, Brussels, 9.11.2016, Swd (2016) 364, Final

${ }^{5}$ European Commission, Commission Staff Working Document Albania 2019 Report, Brussels, 29.5.2019, Swd (2019) 215 Final, 3
} 
In June 2018, the Council set out the path towards opening accession negotiations in June 2019, without any conditionality. In such a "slow and troublesome journey"1, as Michele Comelli qualifies the Albania's EU integration process, Albania still has so much to do.

\section{Conclusions}

Diplomatic relations between Albania and European Union were established since 1991, but the European perspective for Albania became more certain when Stabilization and Association Pact was signed in 1999. After that, Albania intensified its cooperation with the EU in political, economic and legal aspects. In 2003 negotiations on Stabilization and Association Agreement started entering into power in 2009, a moment when Albania submitted its request for obtaining the status of candidate country and achieved it in 2014. Today, in 2019 Albania is waiting for opening the negotiations on EU membership.

Strict conditionality in all stages of enlargement process helps the consolidation of reforms in all candidate and potential candidate countries in fulfilling their obligations after accession. The progress of each country towards the European Union depends largely on other individual efforts in complying with the Copenhagen criteria and conditions of the Stabilization and Association Pact. Within a strict still fair conditioning framework, where the principle of self merits is essential, the perspective of accession encourages political and economic reforms, transforms societies, consolidates the rule of law and creates new opportunities for citizens and businesses in times of economic stagnation, softens the risk of resistance against essential reforms. The credibility of enlargement process is determining for the success of each of the countries. Preserving the momentum for enlargement and reforms all the same, are two sides of the same coin.

The situation with Albania is unprecedented; there is no case like that in the story of EU where the request of a candidate country is denied consecutively. The greatest obstacles along Albania's journey towards the EU integration are pointed out through the progress reports issued by the European Commission repeatedly. Most critics on the consecutive refusals for the status were related to inconsistency of the political criteria of the Copenhagen Charter. Regardless the refusal, the European Commission set 12 priorities for the Albanian government and politics in 2010. Five of these priorities were related to the political situation in the country.

Political development in country: political instability, political polarization, fragile democracy; lack of democratic culture; corruption and organized crime are obstacles for Albania's EU integration process.

\section{Bibliography}

[1] Avdyli Drita, Bektashi Gentiana, "Shqipëria në procesin e liberalizimit e regjimit të vizave të BE-Hapat dhe reformat e ndërrmara," në, Third International Conference on Business, Law, Administration and Social Sciences (Tiranë: TBU, 2015)

[2] Comelli Michele, "Le relazioni tra l'UE e l'Albania," në L'Albania verso l'Unione Europea: il ruolo dell'Italia, në IAI 09 (Romë: Istituto Affari Internazionali,2009)

[3] Council of the European Union, Interim Agreement on Trade and Trade-Related Matters between the European Community and the Republic Of Albania, (Brussels: 22 May 2006) 8154/06 COWEB

[4] European Commission, Staff Working Paper, Albania, Stabilisation and Association Report 2004, (Brussels, April 2004), Com (2004) 203 final

[5] European Commission, Staff Working Paper, Albania 2010 Progress Report (Bruksel: 9 nëntor 2010), COM (2010) 680

[6] European Commission, Commission Opinion on Albania's application for membership of the European Union (Brussels, 9.11. 2010), COM (2010) 680

[7] European Commission, Staff Working Paper, Albania 2011 Progress Report (Bruksel, 12.10.2011), COM (2011) 666 final

[8] European Commission, Enlargement Strategy and Main Challenges 2012-2013 (Brussels, 10.10.2012), COM (2012) 600 final

\footnotetext{
${ }^{1}$ Michele Comelli,"Le relazioni tra I'UE e l'Albania," in L'Albania verso I'Unione Europea: il ruolo dell'Italia, në IAI09, Istituto Affari nternazionali, Roma 2009, 8 
[9] European Commission, Staff Working Paper, Albania 2013 Progress Report (Bruksel: 16.10.2013), COM (2013) 700 final

[10] European Commission, Enlargement Strategy and Main Challenges 2013 - 2014 (Brussels: 16.10.2013), COM (2013) 700 final

[11] European Commission, Albania's Progress in the Fight Against Corruption and Organised Crime and in the Judicial Reform (Brussels: 4.6.2014), COM (2014) 331 final

[12] European Commission, Staff Working Paper, Albania 2014 Progress Report (Brussels: 8. 10. 2014), COM (2014) 700 final

[13] European Commission, Enlargement Strategy and Main Challenges 2014-15 (Brussels: 8.10.2014), $\operatorname{COM}(2014) 700$ final

[14] European Commission, Commission Staff Working Document Albania 2016 Report, Brussels, 9.11.2016 Swd (2016) 364 Final

[15] European Commission, Commission Staff Working Document Albania 2019 Report, Brussels, 29.5.2019 Swd(2019) 215 Final

[16] European Commission, How does a country join the EU, [online] available in:

[17] http://ec.evropa.eu/enlargement/enlargement_process/accession_process/how_does_a_country_join_the_eu/ sap/zagreb_summit_en.htm, retrieved on12.09. 2012

[18] Interview with Olli Rehn, EU Commissioner for Enlargment. (Brussels on 13.2.2006)[online] available in: http://www.seetvexchanges.com/, retrieved on 15. 12. 2012

[19] ITAP, Çështje të eksperiences lidhur me PSA dhe MSA, pjesa I

[20] Këshilli i Ministrave, Strategjia kombëtare për zhvillim dhe integrim 2007 - 2013 (Mars 2008)

[21] Këshilli i Ministrave, Plani Kombëtar për Zhvillim dhe Integrim 2014 - 2020, Draft (qershor 2013)

[22] Rudan Marjanović Ana,"Advocacy Strategy for the EU Integration of the Western Balkans - Guidelines," nëAdvocacy Strategy for the EU Integration of the Western Balkans, European Movement in Serbia (Belgrade: 2016)

[23] Stabilization and Association Agreement between EU and Albania, Official Journal of the European Union, L 107/166 (28.4.2009)

[24] The World Bank, Europe and Central Asia Region, "Stabilization and Association Process in the Balkans," Policy Research Working Paper 3108 (August 2003)

[25] Yiannis Zahariadis, The Effects of the Albania-EU Stabilization and Association Agreement: Economic Impact and Social Implications, ESAU Working Paper 17, ODI, (London: 2017)

[26] Vurmo Gjergji, Relations of Albania with the EU (Tiranë: Institute for Democracy and Mediation, 2008) 